\title{
Epidemiological, Clinical and Biological Aspects of Kidney Disease in People Living with HIV Naive Antiretroviral Therapy at CHU Sylvanus Olympio of Lome (TOGO)
}

\author{
Kossi Akomola Sabi ${ }^{*}$, Badomta Dolaama1, Eyram Yoan Makafui Amekoudi1, \\ Awereou Kotosso ${ }^{2}$, Befa Noto-Kadou-Kaza1, Claude Mawufemo Tsevi1, \\ Komlan George Tona ${ }^{1}$, Eugene Ametepe Attisso ${ }^{1}$, Schyldia Bonou-Selegbe ${ }^{1}$, \\ Hamat Ibrahim³, Guillaume Abderhamman Mahamat ${ }^{3}$, Jaques Vigan4, \\ Majeste Ihou Wateba ${ }^{2}$
}

${ }^{1}$ Service de Néphrologie et Hémodialyse, CHU Sylvanus Olympio, Lomé, Togo

${ }^{2}$ Service des Maladies Infectieuses et Tropicales du CHU Sylvanus Olympio de Lomé, Lomé, Togo

${ }^{3}$ Service de Néphrologie et d'Hémodialyse, Hôpital Universitaire de N'djaména, N'djamena, Tchad

${ }^{4}$ Clinique de Néphrologie, CNHU, Cotonou, Bénin

Email: *kossi.sabi@gmail.com

How to cite this paper: Sabi, K.A., Dolaama, B., Amekoudi, E.Y.M., Kotosso, A., Noto-Kadou-Kaza, B., Tsevi, C.M., Tona, K.G., Attisso, E.A., Bonou-Selegbe, S., Ibrahim, H., Mahamat, G.A., Vigan, J. and Wateba, M.I. (2019) Epidemiological, Clinical and Biological Aspects of Kidney Disease in People Living with HIV Naive Antiretroviral Therapy at $\mathrm{CHU}$ Sylvanus Olympio of Lome (TOGO). Open Journal of Nephrology, 9, 26-34.

https://doi.org/10.4236/ojneph.2019.91003

Received: February 21, 2019

Accepted: March 23, 2019

Published: March 26, 2019

Copyright $\odot 2019$ by author(s) and Scientific Research Publishing Inc. This work is licensed under the Creative Commons Attribution International License (CC BY 4.0).

http://creativecommons.org/licenses/by/4.0/ (c) (i) Open Access

\section{Abstract}

Introduction: Human immunodeficiency virus (HIV) infection is a common cause of kidney disease worldwide. HIV-related renal diseases are associated with high morbidity and mortality in Sub-Saharan African countries. The aim is to describe the epidemiological, clinical and biological aspects of kidney disease in people living with HIV naive antiretroviral therapy in Lomé in Togo. Methods: This was a cross-sectional study done in the department of Infectious and Tropical Diseases in Lomé from ESOPE database. Gomerular filtration rate (GFR) was calculated using the Modification of Diet in Renal Disease (MDRD) equation. Kidney disease was defined as GFR less than 90 $\mathrm{mL} / \mathrm{min} / 1.73 \mathrm{~m}^{2}$. Results: In total, $3118 \mathrm{HIV}$-infected ART-naive patients were included in this study. Among them, the prevalence of renal disease at the beginning of their care, was $41.8 \%$ or 1303 patients [95\% CI: $40.0 \%$ 43.5\%]. The median estimated GFR was $94.7 \mathrm{ml} / \mathrm{min} / 1.73 \mathrm{~m}^{2}: 2.9 \%$ had eGFR $<15 \mathrm{ml} / \mathrm{min} / 1.73 \mathrm{~m}^{2}$. The median age was 40 years [IQR $=34-48$ years] with a sex ratio at 0.45 . BMI median was $20.6 \mathrm{Kg} / \mathrm{m}^{2}$. Most of patients $(30.8 \%)$ were at clinic OMS stage 1 . Median CD4 was 165/uL [IQR = $72-274 / \mathrm{uL}$; median hemoglobin was $10.4 \mathrm{~g} / \mathrm{dl}$ [IQR $=8.8-11.9 \mathrm{~g} / \mathrm{dl}$ ]; median glycemia was $0.84 \mathrm{~g} / \mathrm{l}[\mathrm{IQR}=0.75-0.95 \mathrm{~g} / \mathrm{l}]$. Most of patients (99.9\%) had HIV-1. 8.5\% had hyperleukocytosis, and all patients had thrombopenia. Conclusion: The 
incidence of kidney disease is high in Togolese HIV-infected ART naive patients.

\section{Keywords}

HIV, Kidney Disease, Prevalence, Togo

\section{Introduction}

Renal involvement of the Human Immunodeficiency Virus (HIV) has been described for the first time by Rao et al. in 1984 [1]. There are usually two types of kidney involvement: specific kidney damage and non-specific damage [2]. In 2007, a multicenter study in 31 countries in Europe, Asia and North America among people living with HIV (PLHIV) reported a prevalence of $4.7 \%$ of chronic renal failure [3]. In sub-Saharan Africa, several studies have been carried out, each using different criteria for diagnosing kidney failure: it has been noted therefore a prevalence of renal disease of $6 \%$ in South Africa [4], 25\% in Kenya [5] and $42 \%$ in Brazzaville [6].

Although Togo initiated its first national multisectoral strategy to fight HIV/AIDS and sexually transmitted infections in 2002, few studies have been conducted on kidney damage in HIV [7]. Hence this work, aims to describe the epidemiological, clinical and biological aspects of kidney disease in people living with HIV and naive antiretroviral therapy.

\section{Methodology}

Our study was conducted by the Department of Infectious and Tropical Diseases at the Sylvanus Olympio University Hospital in Lomé. It was a descriptive cross-sectional study of people living with HIV (PLHIV) who were registered at the initiation of ARV therapy. Our study period was from August 18, 2009 to March 25, 2017 or 7 years 7 months.

The data from the questionnaire were extracted from the ESOPE database (Evaluation and Operational Monitoring of ESTHER Programs) version 5. We included all people living with HIV naive antiretroviral therapy who performed a serum creatinine test upon initiation of treatment.

The parameters studied were:

- socio-demographic data: age, sex, place of residence;

- clinical data: blood pressure, body mass index (BMI);

- biological data: HIV type, estimated glomerular filtration rate calculated using the MDRD formula, hemoglobin level, CD4 count, glycemia, white blood cell count, platelets, triglyceride levels, and transaminase.

Renal disease: it is defined by an estimated Glomerular Filtration Rate less than $90 \mathrm{ml} / \mathrm{min} / 1.73 \mathrm{~m}^{2}$. The estimated glomerular filtration rate is obtained by calculating the serum creatinine clearance according to the Modification of Diet 
in Renal Diseases (MDRD) simplified formula [8]. Capital cities and their suburbs have been defined as urban areas. The rest of the settlements were defined as rural areas. The level of CD4 is measured by flow cytometry with thresholds of normal between 600 and $1200 / \mathrm{mm}^{3}$. With respect to transaminases, we considered the values of Aspartate Amino Transferase. The hemoglobin level is measured by automaton. The count of leukocytes, neutrophils, lymphocytes and platelets is made by automaton with smear control.

The statistical analysis was carried out with the software RStudio version 3.3.2. and Microsoft Excel 2016.

\section{Results}

A total of 5604 patients were recorded during the study period. Among them, $3118(53.6 \%)$ patients had serum creatinine to calculate the estimated glomerular filtration rate. Among them, the prevalence of renal disease at the beginning of their care, was $41.8 \%$ or 1303 patients [ $95 \%$ CI: $40.0 \%$ - 43.5\%].

Table 1 summarizes the sociodemographic, clinical and therapeutic characteristics of the population of patients with kidney disease upon initiation of antiretroviral therapy. The sex ratio $\mathrm{H} / \mathrm{F}$ was 0.45 . The median age was 40 years [IQR $=34-48$ years .

Table 2 presents the biological characteristics of the population of patients with renal disease at initiation of antiretroviral therapy. The median eGFR was $94.7 \mathrm{ml} / \mathrm{min} / 1.73 \mathrm{~m}^{2}$ [IQR $=77.3-113.5 \mathrm{ml} / \mathrm{min} / 1.73 \mathrm{~m}^{2}$ ]. The median CD4 count was $165 / \mu \mathrm{l}[\mathrm{IQR}=72-274 / \mu \mathrm{l}]$. The median triglyceride level was $1.59 \mathrm{~g} / \mathrm{l}$ $[\mathrm{IQR}=1.25-1.90 \mathrm{~g} / \mathrm{l}]$. The median hemoglobin level was $10.4 \mathrm{~g} / \mathrm{dl}[\mathrm{IQR}=8.8-$ $11.9 \mathrm{~g} / \mathrm{dl}]$. The median blood glucose level was $0.84 \mathrm{~g} / 1$ [IQR $=0.75-0.95 \mathrm{~g} / \mathrm{l}]$. The median leukocyte was $4700 / \mathrm{mm}^{3}\left[\mathrm{IQR}=3700-6300 / \mathrm{mm}^{3}\right]$. The median platelet count is $24,400 / \mathrm{mm}^{3}\left[19,200-99,000 / \mathrm{mm}^{3}\right]$. The median transaminase was $30 \mathrm{IU} / \mathrm{l}[\mathrm{IQR}=21-44 \mathrm{IU} / \mathrm{l}]$. Viral load was only reported in four (4) individuals with a median of 33,948 copies $/ \mathrm{ml}$ [IQR $=4516-584,000$ copies $/ \mathrm{ml}$ ]. Regarding their ARV treatment, it was only specified in 1300 patients and included tenofovir disoproxil fumarate (TDF) in 502 people or $38.5 \%$ of cases.

\section{Discussion}

Based on the estimation of glomerular filtration rate by calculation of creatinine clearance by the simplified MDRD formula, it is much better than the Cockcroft and Gault equation because it is indexed to body surface area and not to the muscle mass. The Infectious and Tropical Diseases service is not the only site for the care of PLHIV in Togo. It brings together all cases of PLHIV of CHU Sylvanus Olympio and surrounding neighborhoods, and cases of relatively severe patients with many comorbidities. This may overestimate kidney disease cases in our sample. Our results are therefore not transferable to the general population.

The absence of proteinuria is a real limitation because proteinuria is neither supported by the HIV program nor at the expense of the patient. Minimum 
Table 1. Sociodemographic, clinical and therapeutic characteristics.

\begin{tabular}{|c|c|c|c|}
\hline & \multicolumn{3}{|c|}{ Together $(n=3118)$} \\
\hline & $N$ & $\mathrm{n}$ & $\%$ \\
\hline Gender & 1303 & & \\
\hline Male & & 410 & 31.5 \\
\hline Female & & 893 & 68.5 \\
\hline Age (years) & 1303 & & \\
\hline$[4-40]$ & & 514 & 39.4 \\
\hline$[40-84]$ & & 789 & 60.6 \\
\hline High blood pressure ( $\mathrm{mm} \mathrm{Hg}$ ) & 940 & & \\
\hline$[60-100]$ & & 240 & 25.5 \\
\hline$[100-140]$ & & 700 & 74.5 \\
\hline Place of residence & 1215 & & \\
\hline Rural & & 75 & 6.5 \\
\hline Urban & & 1081 & 93.5 \\
\hline BMI $\left(\mathrm{kg} / \mathrm{m}^{2}\right)$ & 129 & & \\
\hline$\leq 25$ & & 113 & 87.6 \\
\hline$>25$ & & 16 & 12.4 \\
\hline WHO clinical stage & 1287 & & \\
\hline 1 & & 397 & 30.8 \\
\hline 2 & & 284 & 22.1 \\
\hline 3 & & 265 & 20.6 \\
\hline 4 & & 341 & 22.5 \\
\hline
\end{tabular}

BMI: Body mass index, WHO: World health organization.

urine strip data at least should be available and 24-hour proteinuria in patients. Proteinuria is the best marker of glomerular damage. The ratio of albuminuria on creatinuria was subdivided into 3 categories that define the prognosis ofevolution of the chronic renal disease [9]. Albuminuria is directly correlated with cardiovascular risk in all patients with chronic renal disease [10].

The hospital prevalence of renal disease in ART-naive patients was $41.8 \%$. Apart from Msango's work in Tanzania, which has a prevalence of $63.7 \%$ [11] higher than ours, all similar work in Africa has a lower prevalence than our result. Ekat in Brazzaville [6], Anyabolu in Nigeria [12] found respectively a prevalence of $42 \%$ and $22.5 \%$. The difference in methodology is the main explanation for this great variability of prevalence in these different works. Indeed, Msango in Tanzania [11] used the Cockroft and Gault equation, which is known to underestimate eGFR in patients with low muscle mass. In the Anyabolu [12] and Ekat [6] studies, kidney disease was defined based on renal failure values of $60 \mathrm{ml} / \mathrm{min} / 1.73 \mathrm{~m}^{2}$, thus neglecting the two stages preceding the moderate renal 
Table 2. Biological characteristics of the patient population.

\begin{tabular}{|c|c|c|c|}
\hline & \multicolumn{3}{|c|}{ Together $(n=3118)$} \\
\hline & $N$ & $\mathrm{n}$ & $\%$ \\
\hline CD4 level $(/ \mu \mathrm{l})$ & 1277 & & \\
\hline$[0-200]$ & & 751 & 58.8 \\
\hline$[200-500]$ & & 462 & 36.2 \\
\hline 500 and over & & 64 & 5 \\
\hline Hemoglobin level (g/dl) & 1251 & & \\
\hline$[1-8]$ & & 211 & 16,9 \\
\hline$[8-10]$ & & 355 & 28.4 \\
\hline$[10-12]$ & & 404 & 32.3 \\
\hline$[12-25]$ & & 281 & 22.5 \\
\hline Typpe of HIV & 1303 & & \\
\hline 1 & & 1297 & 99.5 \\
\hline 2 & & 4 & 0.3 \\
\hline 1 and 2 & & 2 & 0.2 \\
\hline Glycemia (g/l) & 1121 & & \\
\hline$[0-0.7]$ & & 137 & 12.2 \\
\hline$[0.7-1.1]$ & & 869 & 77.5 \\
\hline$[1.1-2]$ & & 104 & 9.2 \\
\hline$[2-4]$ & & 11 & 1.1 \\
\hline Hepatic transaminase (UI/l) & 1215 & & \\
\hline$<31$ & & 646 & 53.2 \\
\hline$[31-300]$ & & 564 & 46.4 \\
\hline$>300$ & & 5 & 0.4 \\
\hline Triglyceridemia (g/l) & 350 & & \\
\hline$<0.35$ & & 4 & 2.3 \\
\hline$[0.35-1.35]$ & & 122 & 70.9 \\
\hline$>1.35$ & & 46 & 26.8 \\
\hline Leukocytes $\left(/ \mathrm{mm}^{3}\right)$ & 921 & & \\
\hline$<4000$ & & 301 & 32.7 \\
\hline$[4000-10,000]$ & & 542 & 58.8 \\
\hline$>10000$ & & 78 & 8.5 \\
\hline Platelets $\left(/ \mathrm{mm}^{3}\right)$ & 681 & & \\
\hline$<50,000$ & & 631 & 92.7 \\
\hline$[50,000-100,000]$ & & 50 & 7.3 \\
\hline
\end{tabular}

disease stage. Mouhari [13] in his work on the biological profile of patients at the initiation of ARV treatment in 2011, performed in the same department found a 
prevalence of $33.2 \%$, significantly lower than our result due to the methodological threshold. Despite this wide variability, the common is that the prevalence of kidney disease in ART-naive patients is significant. Indeed, in several nephrology works in Black Africa, HIV is cited as the third leading cause of chronic kidney disease behind high blood pressure and diabetes. It is undeniable that the combination of HIV and the chronic kidney disease (CKD) leads to increased mortality, so prevention must be the watchword in HIV programs.

Women were the most represented with a sex ratio $\mathrm{H} / \mathrm{F}$ of 0.45 as in the previous Mouhari study [13]. Msango [11] and Ekat [6] found respectively 65\% and $66.13 \%$ of women. The CKD in Africa in the general population mainly affects men but in the population of PLHIV, these data are reversed given the prevalence of HIV in the female sex [14]. This trend is limited to the African population. In China, in the work of Cao et al. [15], we note a male predominance with a sex ratio of 2.87. This difference in sex can be explained either by the fact that women consult late because of their cultural weight, or because they are more affected by HIV or by the influence of female hormones such as estrogen. In fact, according to the PNLS Togo, women are more affected by HIV with a sex ratio of 0.54 in the Togolese population; added to this, the stigmatization of the woman who pushes her to consult late in a hospital, at a late stage. The role of hormones is not to be neglected.

The median age was 40 years [IQR $=34-48$ years]. The most represented age group (52.5\%) was that of patients aged 40 to 60 years. For Msango [11], the average age was 36.1 years; in Ekat [6] the median age was 38.84 years [IQR = 33.18 - 46.23 years] and $52.3 \%$ of patients under 40 years. Mulenga [16] found an average age of $33.7 \pm 7.9$ years and Anyabolu [12], found an average age of $38.84 \pm 10.65$ years. These figures are similar in all countries and show that the young adult would be more affected by kidney disease during HIV infection. The young adults, who make up most of the population, would be the most affected by HIV infection and even develop all the kidney damage during the infection. The median BMI was $20.6 \mathrm{~kg} / \mathrm{m}^{2}$ [IQR $\left.=17.7-23.3 \mathrm{~kg} / \mathrm{m}^{2}\right]$ which is like that found by Ekat [6] and Msango [11]. Patients therefore have a normal BMI. This can be explained by the low impact of HIV infection on muscle mass, with most patients being diagnosed in the early stages of HIV infection. The majority $(30.8 \%)$ of the study population was in stage 1 . In Ekat [6], 70.8\% of patients were in WHO stages 3 and 4 . This difference is explained by the methodological difference. Indeed, Ekat [6] has introduced proteinuria data into the diagnosis of kidney disease. This, results in a greater proportion of subjects at late stages of infection.

The median eGFR of the infected patients was $94.7 \mathrm{ml} / \mathrm{min}$ [IQR $=77.3$ $113.5 \mathrm{ml} / \mathrm{min}$ ]. $2.9 \%$ of the patients had eGFR less than $15 \mathrm{ml} / \mathrm{min}$. In Ekat [6], the median value of MDRD-DFGewas $95.59 \mathrm{ml} / \mathrm{min}$ [IQR = $78.76-114.92$ $\mathrm{ml} / \mathrm{min}$ ] and $8.5 \%$ of patients had $\mathrm{eGFR}<60 \mathrm{ml} / \mathrm{min} / 1.73 \mathrm{~m}^{2}$. Anyabolu [12] found an average eGFR of $91.42 \pm 22.98 \mathrm{ml} / \mathrm{min}$. These figures are similar. The 
median CD4 count was $165 / \mu \mathrm{l}[\mathrm{IQR}=72-274 / \mu \mathrm{l}]$. Our results were consistent with those of Ekat [6] who had a median CD4 count of $192 / \mu 1,74.8 \%$ of patients had a CD4 count $<350 / \mu l$, Msango [11], $141 \pm 90 / \mu$ l, Mouhari [13] with a median CD4 count $134 / \mu \mathrm{l}$ and $40 \%$ had a CD $4 \leq 100 / \mu \mathrm{l}$ number and Mulenga [16] with a median CD4 count of $132 / \mu$ l with $23.7 \%$ less than $50 / \mu$ l. Kidney disease appears to occur in patients with weakened immunity. These patients are then exposed to any kind of condition that can lead to kidney disease. The median hemoglobin level was like that found by Mulenga [16] with a median hemoglobin level of $10.3 \mathrm{~g} / \mathrm{dl}$ and $14.2 \%$ who had a hemoglobin level of less than $8 \mathrm{~g} / \mathrm{dl}$ and Mouhari [13] with a median hemoglobin of $10.4 \mathrm{~g} / \mathrm{dl}$, with against $61 \%$ having a hemoglobin level of less than $8 \mathrm{~g} / \mathrm{dl}$. This can be explained by the fact that in Kenya, most are at high altitude; they therefore have a hemoglobin level higher than the population located at the height of the sea.

Most patients in our study (99.9\%) had HIV 1, which was consistent with the figure found by Mouhari (97.5\%) and Attolou 87.23\% [17]. HIV 1 is widely spread around the world. The median triglyceride level was $1.59 \mathrm{~g} / \mathrm{l}$ [IQR $=1.25$ - $1.90 \mathrm{~g} / \mathrm{l}]$. The majority (83.3\%) had normal cholesterol levels. 350 patients had triglyceride levels. The median was $0.95 \mathrm{~g} / \mathrm{l}[\mathrm{IQR}=0.72-2.0 \mathrm{~g} / \mathrm{l}]$. The majority (70.9\%) had normal triglycerides. Anyabolu [12] in Nigeria found similar numbers. Lipid disorders are not common but exist during HIV infection. The median leukocyte was $4700 / \mathrm{mm}^{3}\left[\mathrm{IQR}=3700-6300 / \mathrm{mm}^{3}\right]$ with $8.5 \%$ having hyperleukocytosis. PLHIV are more likely to get infections with leukopenia often. Hyperleukocytosis is rare and most often shows a good immune response. The median transaminase was $30 \mathrm{IU} / \mathrm{l}[\mathrm{IQR}=21-44 \mathrm{IU} / \mathrm{l}]$ with $0.4 \%$ that had transaminases greater than 10 times normal. Mouhari [13] found a similar result. HIV-associated hepatic cytolysis is rare and most often due to co-infection with hepatitis $\mathrm{B}$ and $\mathrm{C}$ viruses or antiretroviral therapy. The median blood glucose level was $0.84 \mathrm{~g} / \mathrm{l}[\mathrm{IQR}=0.75-0.95 \mathrm{~g} / \mathrm{l}]$. Most patients in our study (77.5\%) had normal blood glucose. Mouhari [13] noted a median blood glucose level of $0.69 \mathrm{~g} / \mathrm{l}$. The blood glucose value was normal in $57.2 \%$ of patients. These results were consistent. High blood sugar may indicate poorly balanced diabetes, which could lead to diabetic nephropathy.

\section{Conclusion}

HIV-related renal disease is a reality with female predominance, people over 40 years of age, with a BMI between 18 and $25 \mathrm{~kg} / \mathrm{m}^{2}$, a CD4 count of less than 200/ $\mu \mathrm{l}$, a glycemia level between 0.7 and $1.1 \mathrm{~g} / \mathrm{l}$, a hemoglobin level of less than $8 \mathrm{~g} / \mathrm{dl}$ and WHO stages 2 to 4 . Despite the methodological limitations, we noted a prevalence of $41.3 \%$ kidney disease; which is huge, even in without proteinuria, which is a big marker of kidney disease. It would be beneficial for the data to be better informed. Future work on a longitudinal study will determine the prognosis and progression of patients living with HIV and with kidney disease upon initiation of antiretroviral therapy. 


\section{Conflicts of Interest}

The authors declare no conflicts of interest regarding the publication of this paper.

\section{References}

[1] Rao, T.K., Filippone, E.J., Nicastri, A.D., Landesman, S.H., Frank, E., Chen, C.K., et al. (1984) Associated Focal and Segmental Glomerulosclerosis in the Acquired Immunodeficiency Syndrome. The New England Journal of Medicine, 310, 669-673. https://doi.org/10.1056/NEJM198403153101101

[2] Bourgoignie, J.J., Ortiz-Interian, C., Green, D.F., Jaffe, D.J., Roth, D., Pardo, V. Renal (1990) Complications of Human Immunodeficiency Virus-Type I. In: Andreucci, V.E., Fine, L.G., Kjellstrand, C.M. and Sugino, N., Eds., International Yearbook of Nephrology 1990, Vol. 2, Springer, Boston, MA, 73-88. https://doi.org/10.1007/978-1-4613-1491-2_5

[3] Mocroft, A., Kirk, O., Gatell, J., Reiss, P., Gargalianos, P., Zilmer, K., et al. (2007) Chronic Renal Failure among HIV-1-Infected Patients. Aids, 21, 1119-1127. https://doi.org/10.1097/QAD.0b013e3280f774ee

[4] Han, T.M., Naicker, S., Ramdial, P.K. and Assounga, A.G. (2006) A Cross-Sectional Study of HIV-Seropositive Patients with Varying Degrees of Proteinuria in South Africa. Kidney International, 69, 2243-2250. https://doi.org/10.1038/sj.ki.5000339

[5] Wools-Kaloustian, K., Gupta, S.K., Muloma, E., Owino-Ong'or, W., Sidle, J., Aubrey, R.W., et al. (2007) Renal Disease in an Antiretroviral-Naive HIV-Infected Outpatient Population in Western Kenya. Nephrology Dialysis Transplantation, 22, 2208-2212. https://doi.org/10.1093/ndt/gfm223

[6] Ekat, M.H., Courpotin, C., Diafouka, M., Akolbout, M., Mahambou-Nsonde, D., Bitsindou, P.R., et al. (2013) Prevalence and Factors Associated with Renal Disease among Patients with Newly Diagnoses of HIV in Brazzaville, Republic of Congo. Medicine et Santé Tropicale, 23, 176-180.

[7] UNESCO HIV and Health Education Clearinghouse (2015) Plan opérationnel de lutte contre le Sida et les IST au Togo 2014-2015.

http://hivhealthclearinghouse.unesco.org/library/documents/plan-operationnel-de-1 utte-contre-le-sida-et-les-ist-au-togo-2014-2015

[8] Levey, A.S., Bosch, J.P., Lewis, J.B., Greene, T., Rogers, N. and Roth, D. (1999) A More Accurate Method to Estimate Glomerular Filtration Rate from Serum Creatinine: A New Prediction Equation. Annals of Internal Medicine, 130, 461-470. https://doi.org/10.7326/0003-4819-130-6-199903160-00002

[9] Levey, A.S. and Coresh, J. (2012) Chronic Kidney Disease. The Lancet, 379, 165-180. https://doi.org/10.1016/S0140-6736(11)60178-5

[10] Halimi, J.-M., Hadjadj, S., Aboyans, V., Allaert, F.-A., Artigou, J.-Y., Beaufils, M., et al. (2007) Microalbuminurie et excrétion urinaire d'albumine: Recommandations pour la pratique clinique. Néphrologie Thérapeutique, 3, 384-391. https://doi.org/10.1016/j.nephro.2007.05.001

[11] Msango, L., Downs, J.A., Kalluvya, S.E., Kidenya, B.R., Kabangila, R., Johnson, W.D., et al. (2011) Renal Dysfunction among HIV-Infected Patients Starting Antiretroviral Therapy. AIDS, 25, 142-1425. https://doi.org/10.1097/QAD.0b013e328348a4b1

[12] Anyabolu, E.N., Chukwuonye, I.I., Arodiwe, E., Ijoma, C.K. and Ulasi, I. (2016) Prevalence and Predictors of Chronic Kidney Disease in Newly Diagnosed Human 
Immunodeficiency Virus Patients in Owerri, Nigeria. Indian Journal of Nephrology, 26, 10-15. https://doi.org/10.4103/0971-4065.156115

[13] Mouhari-Toure, A., Patassi, A., Nabroulaba, K.T., Djadou, K.E., Edou, K., Nyametso, D., Aho, K., Saibou, A., Kombaté, M., Kpanla, K., Niman, K.W., Togbossi, A., Agodomou, E., Wotogbe, A., Tadona, M., Singo, A., Déku, K. and Pitche, P. (2011) Biological Profile of Adult Patients Infected with HIV at Initiation of Antiretroviral Therapy in Togo. Médecine et Maladies Infectieuses, 41, 229-234. https://doi.org/10.1016/j.medmal.2010.11.007

[14] ONUSIDA (2018) Togo. http://www.unaids.org/fr/regionscountries/countries/togo

[15] Cao, Y., Gong, M., Han, Y., Xie, J., Li, X., Zhang, L., et al. (2013) Prevalence and Risk Factors for Chronic Kidney Disease among HIV-Infected Antiretroviral Therapy-Naive Patients in Mainland China: A Multicenter Cross-Sectional Study. Nephrology, 18, 307-312. https://doi.org/10.1111/nep.12031

[16] Mulengam, L.B., Kruse, G., Laki, S., Centrell, R.A., Reid, S.E., Zulu, I., Stringer, E.M., et al. (2008) Baseline Renalin Sufficiency and Risk of Death among HIV-Infected Adults on Antiretroviral Therapy in Lusaka, Zambia. AIDS, 22, 1821-1827. https://doi.org/10.1097/QAD.0b013e328307a051

[17] Attolou, V., Bigot, A., Ayivi, B. and Gninafon, M. (1998) Renal Complications Associated with Human Acquired Immunodeficiency Virus Infection in a Population of Hospital Patients at the Hospital and University National Center in Cotonou. Sante, 8, 283-286. 